\title{
WOMEN WRITERS OF EARLY MODERN SPAIN: A FEMINIST OVERVIEW
}

\section{DONES ESCRIPTORES DE LA PRIMERA EDAT MODERNA ESPANYOLA: UNA MIRADA FEMINISTA}

\author{
Anne J. CRuz \\ University of Miami \\ ajcruz@miami.edu
}

Abstract: Spanish women writers of the early modern period have consistently been undervalued owing to the lack of documentation available. New research, however, has uncovered many more female authors than previously known and has also dedicated time to the study of their historical context such as their education and social status. Women's cultural production may thus be divided by religious and secular women, as well as by noble and non-noble women, although all contributed to such literary genres as poetry, novels, short stories, and plays. Women writers also took up the pen to write ego-documents such autobiographies, conventual foundational histories, and correspondence, and numerous women participated in literary academies and tournaments. Most importantly, however, women writers created and participated in their own lettered communities.

Key words: women writers, feminist scholarship, early modern Spain, ego-documents, literary genres, convents, political treatises, correspondence, theater.

Resum: Les escriptores espanyoles de la primera edat moderna no han rebut l'atenció que calia, en gran part per la manca de documentació. Els esforços recents d'investigadors feministes, però, han trobat més escriptores de les que es coneixien anteriorment. Aquests investigadors s'han dedicat a l'estudi del seu context històric, com ara l'educació i el nivell social. Cal distingir la producció cultural femenívola d'aquella que prové de religioses o seglars, i també de les elits o no-elits, encara que totes van contribuir als gèneres literaris de poesia, novel.les, contes curts o obres de teatre. Les escriptores també es van dedicar a escriure, a més, els anomenats egodocuments, com ara autobiografies, històries fundacionals de convents o epistolaris, a més de participar en acadèmies 
Anne J. Cruz

Women Writers of Early Modern Spain: A Feminist Overview

literàries $\mathrm{i}$ justes poètiques. Tanmateix, el més significatiu en aquest cas és que a través dels seus escrits van crear i van participar en el que podrien anomenar-se comunitats lletrades de dones.

Paraules clau: escriptores, estudis feministes, primera edat moderna espanyola, memòria personal, gèneres literaris, tractats polítics, correspondència, teatre.

cos es es

In her prologue to Novelas amorosas y ejemplares, "Al que leyere», María de Zayas claims that readers will no doubt be astounded by a woman's nerve, not only to write a book, but to publish it. Some fools, she says, will even take it as madness that a woman would be so brash, since women, in their opinion, are incapable of such a task. Zayas's defense of women lays the blame squarely on men's tyranny for not allowing them the right to an education, and to buttress her case, she gives several examples of successful women writers from history (Olivares 2000: I59-I6I). Zayas herself is an example of a woman whose publications garnered her the title of «sibyl» and «immortal». As her modern editor Julián Olivares states, however, despite being «the most famous Spanish woman writer of her time», very little is known about her. Since we do not know what kind of an education she received, he proposes that she may have been an autodidact, "as were most likely the majority of women writers of that time». ${ }^{1}$ Zayas's biographers have pieced together parts of her life, some from what her novels relay, others from information gleaned from literary documents that reference her, such as the vejamen by Francesc Fontanella found by Kenneth Brown, which situates her at a literary academy in Barcelona in I643 (Brown 1993). As is typical of most histories of women writers, however, information about her life remains scarce; while her birthdate is given as September I2, I590, neither her main place of residence nor the year she died is available. In its omissions, therefore, Zayas's biographies exhibit the same gaps as do those of most other female authors.

Despite these silences, much has been increasingly learned about early modern women writers. Zayas is right, of course, that the lack of educational opportunities severely limited the potential of female writers. Yet the numbers of women who wrote in early modern Spain, even though they may not have published their work, were larger than previously ascertained. The need to investigate the lives of early modern

I. «De su educación no tenemos noticia. Aunque debe haber tenido un preceptor que la enseńase a leer y escribir, doña María probablemente fue autodidacta, como deben haberlo sido la mayoría de las escritoras de su tiempo" (Olivares 2000: II-I2). 
women has spurred feminist scholars to research archival documents and early modern practices for new data, for information that might shed light on women's lives, and recover the identities of unknown women authors. This research activity intensified throughout the twentieth century, thanks to feminism's second wave, expanding our knowledge of female productivity across the various kinds of cultural discourses, and generating modern editions of female-authored texts and new contextual studies (Gilmore 2008). Feminists' interest in women's writing, for instance, led to inquiries about their education, as women's levels of schooling and literacy directly affected their capacity to write (Howe 20I6; Cruz \& Hernández 20II). While exact figures are not available, the percentages of women who were literate have been estimated to vary from town or city to town and according to social class. ${ }^{2}$

\section{WOMEN'S EDUCATION AND LITERACY}

Studies focusing on female education show that lower- to middle-class girls attended convent schools and lay girls' schools (escuelas de amigas), both usually founded in urban areas with large populations (Cruz 2018: 27-40). ${ }^{3}$ Royal and aristocratic girls were typically taught by tutors, and even wealthy middle-class families hired outside tutors to teach their children. Most likely, well-known women writers such as Zayas received the latter kind of education. As scholars have indicated, most writers were from the higher social ranks, either nobles or middle class, and lived in urban surroundings that made cultural products such as novels, poetry, and the theater easily available to them. Indeed, women shared to some degree the heady intellectual atmosphere of humanism that permeated the early modern world. Renaissance libraries owned by Isabel of Castile and Mencía de Mendoza, for example, exhibit large collections on many subjects, but recent research on women's inventories ascertain that middle-class women were also often the owners of books, the quantity and quality of which varied according to their social rank. Women also had access to their male relatives' libraries that facilitated their knowledge of male-authored texts and expanded their literacy beyond their schooling (Dadson 1998; Cátedra \& Rojo 2004).

2. The highest literacy rates of early modern Spanish women have been ascribed to Ávila, with $64 \%$ for noblewomen; and Barcelona, with 45 to $55 \%$ for noblewomen and wives of merchants (cited in Baranda Leturio 2005: 20-2I). These percentages are most likely excessive, however, and probably did not exceed 30-35\%; rural women are capped at $\%$ (Baranda Leturio 2005: 2I).

3. For much of the information in this article, I have relied on N. Baranda Leturio \& Anne J. Cruz (2018).

Caplletra 67 (Tardor, 2019), p. 129-143 
Nevertheless, not all women who could write did so. Authoring a literary work not only entailed knowing how to write well and being familiar with male-authored texts that women often appropriated, whether as models or as challenges to their own writings; it also meant that women assumed the psychological assurance that what they wrote was of value and would be appreciated. The latter concern is most evident in the rhetoric with which women defended their right to script their own thoughts, sentiments, and ideas. Writing was still considered a subversive act for women, who while taught to read, were still enjoined not to write by moralists influenced by the Pauline stricture that women must keep quiet in church. Viewed as intellectually inferior, women were not supposed to develop rational thought; if they wrote, therefore, it was because God illuminated their spirit. Both secular and religious women frequently protected themselves from censure through expressions of humility and modesty tropes. As is well known, Teresa of Ávila strategically assumed these stereotypes of women's ignorance and timidity in her writings (Weber 1990; Pender 2012). The secular author, Isabel de Liaño's (s. XVII) prologue to her epic hagiographic poem, Historia de la vida, muerte y milagros de santa Catalina de Sena (1604), reveals her caution in writing as a woman with little or no aristocratic affiliations. She states that she does not wish to challenge women's inferiority, but as a «simple mujer», and calls on God to defend her temerity, owing as she does her new literary ability to him (Cruz 2003: III).

While both religious and secular women authors relied on rhetorical strategies that would grant their writings the authorization by state and church for their publication, it is helpful to regard the two groups separately. This division in the main not only served to distinguish between the sacred and profane topics ascribed by women writers to their literary texts — there was some cross-over between thembut also to acknowledge their different life experiences. Given Spain's Catholicism, it is not unrealistic to assume that nuns would be in the majority; in fact, the number proposed for women living in convents in Italy, Spain, and the New World during the seventeenth century, including young girl students who had not yet professed, is over 80,000 (Evangelisti 2007: 47). Although the figures may be impressive, far fewer women would dedicate themselves to writing, despite the mandates given many of them by their confessors to pen their autobiographies. Correlatively, secular women, most of whom ran households and cared for children, had less time to write. The classic anthology by Manuel Serrano y Sanz, published in the early I90os, listed several hundred women writers between 1500 and I800; an approximate number of both secular and religious women writers is offered by the ongoing data base BIESES (Biblioteca de Escritoras Españolas), initiated by Nieves Baranda Leturio in 2004, which lists slightly more than 500 women between I 450 and 1800 whose works are extant. 


\section{RELIGIOUS WOMEN WRITERS}

The first general introduction to Hispanic convent culture that appeared in the United States was the collection Untold Sisters by Electa Arenal and Stacey Schlau, published in 1989. Since then, there has been an onrush of publications on religious women writers that have shown the breadth and scope of their writings, despite their fact that few if any works were published in the nuns' lifetime. The works of the most important religious woman writer, Teresa of Ávila (I515-1582), are significant in that they deeply influenced and set the standard for all other religious women's writings. Although the collected works were published as early as I9I7 by Silverio de Santa Teresa, feminist approaches began much later with studies by Alison Weber and Gillian Ahlgren, among others. Arenal and Schlau's anthology contributed, along with Weber and Ahlgren, to a feminist consciousness of religious women writers as a group. The view of women as forming a community of writers permits a greater appreciation of their contribution to literary history, as a broader concept of genre studies that no longer necessitates constant comparisons with male writers. This is true especially for nuns, as their works, produced in tightly-knit female communities, spread beyond their walls to other convents, creating a lettered world informed by their spiritual sensibility.

The most recognized genre of conventual writing is the autobiography, influenced by Teresa of Ávila, whose Life (El libro de la vida) served as its model, and which narrated the author's religious experiences. The majority of these ego-documents were written by mandate of the nun's confessor as a guide against demonic delusions and temptations and to ensure her orthodoxy and progress in Tridentine Christian virtues, with the ultimate goal of leaving sufficient biographical material for the nun's possible canonization. Autobiographies relied on the author's examination of her life from within, as convents remained cloistered following Tridentine decree. The autobiographies spoke to their authors' spiritual growth, mystical experiences, and desire for union with God. Other narratives penned by nuns related the histories of other nuns' lives, such as chronicles, biographies, and hagiographies. Unlike autobiographies, which documented the authors' internalized spirituality, these narratives instead required an expansive gaze outward toward the author's surroundings; in this light, nuns also wrote foundational narratives of their convents, another genre that imitated Teresa of Ávila's writings, this time, her Foundations (Libro de fundaciones) (Poutrin 2018; Marcos Sánchez 20I8; Donahue 2018). Thus, the nuns who wrote about their order not only formulated its particular history, but created models for other foundational activities, some of which took place outside Spain, such as the Discalced Carmelite convents founded in France and Lisbon, or those founded in the New World, like the Franciscan convent founded in the Philippines (Owens 2009; 2017).

Caplletra 67 (Tardor, 2019), p. 129-143 
The second most recognized literary genre by nuns is that of poetry, whose poetic models were Teresa of Ávila and John of the Cross. The poems were frequently gathered in songbooks (cancioneros), and similarly to the autobiographies and historical narratives, were hardly, if ever, published. Nevertheless, they often circulated both within and outside convent walls, as they spread to other convents to be shared. As was to be expected, nuns' poetry exalted religious sentiment, in particular, the asceticmystical poetry that identified with and intended to replicate Christ's Passion (Olivares 1995). Such poetry spiritualized the secular love poems of both the popular songbook and cultured Petrarchan traditions. Demonstrating the authors' diverse educational backgrounds and knowledge of poetic convention, the poems encompass cultured forms such as the sonnet and lira, as well as traditional songs and ballads, while the religious imagery utilized by numerous nun-poets reflects a gender-inflected view of nature and the self (Olivares 2009a; Schlau 2018).

Other forms of cultural production by religious women writers included theater, yet this genre has in the main been lost to us, as few playscripts survive. Nonetheless, the works of Lope de Vega's daughter, Sor Marcela de San Félix (I605-1687), and of Sor Francisca de Santa Teresa (1654-1707), as well as other nuns allow entry into religious theater, based on the Catholic liturgical calendar. These plays served different functions: they instructed nuns on how to behave and served as a guide to the ascetic life. According to Carmen Alarcón Román, plays like Francisca de Santa Teresa’s Coloquio al nacimiento de nuestro Redentor or Sor Marcela de San Félix's allegorical Los coloquios del alma and Muerte del apetito, also disclosed criticism of male authority, especially of confessors' rigor. But plays were also entertainment; nuns took on the roles of actors, directors, and set designers, as well as playwrights. Sor Marcela's plays reveal her sense of humor, as she jokes irreverently about life in the convent. Plays, therefore, allowed nuns to act out their beliefs within the protected confines of the convent. ${ }^{4}$

\section{SECULAR WOMEN WRITERS}

The significance of women's writings can best be appreciated by perceiving the authors not solely as individuals or anomalous players, but as part of a far more expansive panorama of historical agency. Such an approach reveals the scope of women's contribution to cultural production and their creation of and participation in a female-gendered canon, one until recently inexistent. Although religious women

4. For Sor Marcela's complete works, see Arenal \& Sabat-Rivers (1988). 
writers were by far the most abundant in early modern Spain, secular women engaged often in creative activities and practiced a wider variety of genres than did religious women. Unlike their religious sisters, secular women had more opportunities to interact with a broader public; at least two of them, in fact, assumed all the characteristics of professional writers: María de Zayas and Ana Caro Mallén de Soto (c. 1600-1652). Both earned wages from their publications: Zayas, as we have seen, was keenly aware of her status as a published woman author; the publication of her two collections of short stories guaranteed her income and fame. Caro, for her part, was hired by the Madrid city authorities to chronicle in ballad form royal festivities that took place on the Buen Retiro lands and other public events. She was also hired by the cathedral chapter of Seville to chronicle the Corpus Christi celebrations from I64I to I645.

The most well-known female prose fiction writer of early modern Spain, Zayas produced two collections of short stories or novelle influenced by the enormous popularity of the Italian short story writer Boccaccio and his followers, Giraldi Cinthio and Bandello, which were read in translation and in the original. Their urban plots attracted an audience that enjoyed humorous narratives about male-female relations. Her first ten novels, published in frame-tale structure, touch ironically upon the themes of women's disappointment in love, whereas her second collection, published some twenty-five years later, assumes a far more grim and violent tone of deception and abuse. ${ }^{5}$ One of her closer literary models is Cervantes's Novelas ejemplares, yet whose plots she twists to further emphasize her female protagonists' agency (Cruz 2008; Cruz 20I3). Four other women penned novels besides Zayas: Beatriz Bernal (I5OI-?), the first woman to write a chivalric novel; Leonor de Meneses (?-I640); who wrote plays and a novela cortesana under the pseudonym Laura Mauricia; Mariana de Carvajal (I6201670), who wrote novelas cortesanas; and Ana Francisca Abarca de Bolea (I602-1685?), the only nun to write a pastoral frame-tale (Armon 2018). The latter three women's works were published in the second half of the seventeenth century, perhaps because women's fictional writings had become more acceptable by that time, thanks to Zayas and Caro, both of whom were celebrated by male authors.

Although both Zayas and Caro were also known as poets, Zayas's poetry was incorporated in her collections of short stories. However, we have few surviving poems by Caro, although the poet and her possible relation, Rodrigo Caro, claims she actively wrote (Kaminsky 1996: 202). Poetry was a genre that many secular women took up, as male-authored poems were easily available to imitate, whether

5. Although Zayas's first collection is dated I637, at least eight of the novels had already been written by 1625 (Moll 1982).

Caplletra 67 (Tardor, 2019), p. 129-143 
popular variants through oral transmission or cultured poems collected in songbooks. Women's voices could either assume a neutral lyric subject or move to a consciously gendered perspective (Olivares 2009b) According to María Martos, women's poetry frequently presented an ambiguous subject, but that in itself revealed the female poet's intent on gender indeterminism (Martos 2018: 136). Indeed, their poetry often identified as gendered female, as the genre lent itself to women's personal sentiments and experiences (Fox 2008; Olivares \& Boyce 2012). Themes such as familial relations, patronage, motherhood, and marriage question the divide between the private and the public, if only because poetry by women writers, while mostly unpublished, circulated widely. That their poetry was not considered a professional activity, but one relegated to otium, highlighted the authors' reserve, but it could also serve to prove their status in society (Elk 2017: 9).

Explicitly public manifestations of women's poetic production may be traced to their participation in literary academies and tournaments. While academies were private affairs generally promoted by nobles, tournaments aimed toward the public, with the submitted poems exhibited and later recited. As was the case with other literary production, women's participation in academies took place in the seventeenth century, when urbanization increased. Still, though women's presence is mentioned in novels and plays, there is little proof of actual female activity. Women's participation in tournaments, however, has been documented to be decisive: over 250 women took part in sixty tournaments in various cities. Their irregular participation leaves open the possibility of women's restriction in some tournaments (Osuna 20I8; Zuese 20II). Yet, some, like the poetic competition (justa poética) that took place in Zaragoza in I6I7 on the transfer of the relics of San Ramón Nonat, included both religious and secular women writers (Egido 23). For those women who took part in poetic competitions, their poetry could be published in anthologies; a few, however, published their work much less prestigiously in pamphlets. Like Ana Caro, several women published their poetic chronicles of festive occasions and historical events, receiving payment. These women found they could ensure the publication of their brief works in the humble form of pamphlets (Marín Pina 20I8).

By the seventeenth century, the literary field was sufficiently inclusive for women to attempt the most popular genre in the early modern period. It is not unreasonable to assume that women wrote their plays with the intention of staging them; Ana Caro, in fact, received payment for dramatic works written for Seville celebrations. Yet despite the twenty-one known female authors of plays, including religious and colonial playwrights, we have no information on whether any of their works were staged. If a play was published, however, with some adding "comedia famosa» in the 
title, this was an indication that it had been staged (Romero-Díaz \& Vollendorf 2016: 2I-23). The majority of the secular playwrights follow Lope de Vega's revisionary new form of playwriting, the comedia nueva, and focused mostly on point of honor and relations between men and women. As conventional as their plots may seem, the playwrights create situations that highlight the female protagonists. Amy Williamsen states that «even when the plays portray women as objects of desire, they do so in ways that pose challenges to established paradigms» (Williamsen 20I8: 190). Moreover, men are often seriously or comically objectified, inverting their roles within the male patriarchy. Implied in these plays is the authors' belief in the need to call for women's vindication through public means, a shared ideological stance that further creates a female literary community with collective goals.

\section{POLITICAL WRITINGS}

Early modern women wrote beyond the conventional limits of literary genres, demonstrating their interest in social action and their knowledge of politics. From medieval writers Leonor López de Córdoba (I362-I420) and Teresa de Cartagena (I425-?) to Baroque noblewomen Luisa de Padilla, Countess of Aranda (I590-I646) and María de Guevara, Countess of Escalante (?-1683) the ego-documents written by women express their concerns about their personal political experiences and converting them into political issues. López de Córdoba was the first European woman to pen an autobiography; her Memorias are intended as testimony to clear her family name from political stigma, and their veracity reassured through the prayers that are included in the text. The nun Teresa de Cartagena's treatise Arboleda de los enfermos speaks to the dignity of disabled persons, and lauds her deafness as a condition that protects her from any hearing any blasphemous words against God. Teresa defended the treatise's authorship in a second treatise dedicated to another highly educated woman, Juana de Mendoza, lady in waiting to the Infanta Isabel, the oldest daughter of the Catholic Monarchs. Isabel of Castile's court was the first to be systematically concerned with the education of elite humanist women, and it is no coincidence that several learned women, some themselves the daughters of humanists, would converge at court. María Pacheco (I496-I53I), the daughter of Iñigo López de Mendoza, Count of Tendilla, married the Comunero Juan López de Padilla; after his death and having taken on the battle, she escaped to Portugal, where she taught Latin. One Latin teacher who remained in Spain was Beatriz Galindo (I464?-I534, tutor to Isabel and her daughters. Although no writings by her or Pacheco have been found, all these women's humanist learning promoted the lettered culture of Isabel's court.

Caplletra 67 (Tardor, 2019), p. 129-143 
Numerous Spanish erudite elite women resided in various towns and sites besides the court, yet their writings also left proof of their abiding interest in humanist knowledge, intellectual currents, and reformist politics. Luisa Sigea (1530?-1560?), whose humanist Latin dialogue debates the values of courtly and private lives for women, lived mainly in Portugal, where she obtained a position as tutor at the Portuguese court along with her humanist father, who had left Spain with María Pacheco, thanks to her knowledge of languages, including Arabic, Greek, Hebrew and Latin. Oliva Sabuco de Nantes's (1562-1625) New Philosophy of Human Nature (Nueva filosofia del hombre) surprises the reader with its pioneering approach to psychosomatic medicine. ${ }^{6}$ Aristocratic women also contributed to a critique of society: Luisa de Padilla wrote six treatises addressing the education and comportment of the nobility. The first four books intended secular reform, while the last two emphasized moral behavior; all, however, demonstrate her concern for moral philosophy and social reform, and are significant for their approach to women's comportment. Another noble, María de Guevara, Countess of Escalante, wrote two treatises on government, arguing for women's participation in matters of state and war (Bergmann 2018: 226). Asserting her authority, she wrote directly to Philip IV in her treatise Warnings to the Kings and Advice on Restoring Spain (Tratado y advertencias hechas por una mujer celosa del bien de su Rey y corrida de parte de España) (Romero-Díaz 2007).

Letters by women were another form of political writing that verged on the private given their privileged status as missives addressed directly to powerful men and women (Martos \& Neira 2018). One such correspondence was that of the Franciscan nun María Jesús de Ágreda (1602-I665) with Philip IV. Although best remembered for her treatise on the Virgin Mary, The Mystic City of God (La mistica ciudad de Dios), published posthumously and alternatively censored and praised, as well as for her bilocation in the New World, her spiritual and political influence, documented in her more than 600 letters to the monarch, was significant (Baranda 199I). The letters of the self-described missionary, Luisa de Carvajal y Mendoza (I556-I6I4) to the Duke of Lerma's favorite, Rodrigo Calderón, is another example of women's direct influence, as she counsels him on the decisions he should take at court as well as his spiritual development (Levy-Navarro 2005; Cruz 20I4). Other women wrote to their relatives; although the correspondence is called «familiar» and takes up personal and occasional themes such as greetings, condolences, and family news, some also were

6. The book's authorship has come under question and often assigned to Sabuco's father, Miguel Sabuco (Bergmann 2018: 224). However, in the 1622 Braga edition, the book's Portuguese printer, Fructuoso Lourenco de Basto, fully accepts Sabuco's authorship; and Benito Feijoo includes her in his treatise, Defensa de las mujeres [In Defense of Women]. 
intended to serve as advice, such as the abundant letters to the Duke of Pastrana from his mother, Catalina de Mendoza y Sandoval, Duchess of Infantado (I6I6-I686) (Cruz 20I8: 286-287).

As we have seen, the genres that make up the writings by early modern women, from lyrical poetry to political discourses, cannot be classified under rigorous categories. Religious writings often overlap with historical narratives, such as foundational narratives, even as secular humanist treatises address spiritual concerns, as in didactic treatises. The texts following male-authored literary models, as in the case of poems, playscripts, and novels, break from and challenge conventional content and structures to give voice to women's specific concerns, both private and public. As such, the writings disclose the myriad strategies undertaken by their female authors to articulate their views. In evaluating female cultural production, what becomes clear is that it was generated by women from various social levels, who did not hesitate to address their own experiences and apprehensions, whether cloaked in metaphors of humility, written at the behest of confessors, or by exercising aristocratic entitlement. Yet no matter how singular, women's voices do not fail to create and participate in their own lettered communities, expressing their experiences, apprehensions, goals, and aspirations. Although more research is still needed that will, it is hoped, unearth new texts and authors and that will provide wider cultural and socio-historical perspectives, feminist scholarship has opened many windows through which to understand the lives of early modern women.

Anne J. Cruz

University of Miami

ajcruz@miami.edu

ORCID 0000-0003-I297-3240

\section{BIBLIOGRAPHIC REFERENCES}

Ahlgren, G. T. W. (1998) Teresa of Ávila and the Politics of Sanctity, Ithaca, Cornell University Press.

Alarcón Román, M. C., ed. (2007) Sor Francisca de Santa Teresa: Coloquios, Madrid, Arcibel.

Arenal, E. \& G. Sabat-Rivers, eds. (1988) Literatura Conventual Femenina. Sor Marcela de San Félix, hija de Lope de Vega. Obra Completa. Coloquios espirituales, loas y otros poemas. Barcelona, Promociones y Publicaciones Universitarias. [Online: $<$ http://www.intratext.com/IXT/ESLoor4/_PiD.HTM>.]

Caplletra 67 (Tardor, 2019), p. 129-143 
Arenal, E. \& S. Schlau, eds. (1989; 2010) Untold Sisters: Hispanic Nuns in Their Own Works. Albuquerque, University of New Mexico Press.

Armon, S. (20I8) «Novels and Narratives», in N. Baranda Leturio \& A. J. Cruz (eds.), The Routledge Research Companion to Early Modern Spanish Women Writers, New York, Routledge, p. I69-185.

Baranda, C. (I99i) María de Jesús de Ágreda: Correspondencia con Felipe IV, Religión y Razón de Estado, Madrid, Castalia.

Baranda Leturio, N. (2005) Cortejo a lo prohibido: lectoras y escritoras en la España moderna, Madrid, Arco.

Bergmann, E. L. (20I8) «Spain's Women Humanists», in N. Baranda Leturio \& A. J. Cruz (eds.), The Routledge Research Companion to Early Modern Spanish Women Writers, New York, Routledge, p. 219-235.

BIESES = Bibliografía de Escritoras Españolas. [Online: <https://www.bieses.net/en>.]

Brown, K. (1993) «María de Zayas y Sotomayor: escribiendo poesía en Barcelona en época de guerra (I643)», Dicenda. Cuadernos de Filología Hispánica, II, p. 355-360.

Brownlee, M. S. (200o) The Cultural Labyrinth of Maria de Zayas, Philadelphia, University of Pennsylvania Press.

Cátedra, P. M. \& A. Rojo, eds. (2004) Bibliotecas y lecturas de mujeres. Siglo XVI, Soria, El Instituto de Historia del Libro y de la Lectura.

Cruz, A. J. (2003) «Challenging Lives: Gender and Class as Categories in Early Modern Spanish Biographies», in A. J. Cruz, R. Hernández \& J. Tolliver (eds.), Disciplines on the Line: Feminist Research in Spanish, Latin American, and U.S. Latina Women. Newark, DL, Juan de la Cuesta, p. I03-I23.

- (2008) «María de Zayas and Miguel de Cervantes: A Deceitful Marriage», in S. Velasco (ed.), Tradition and Innovation in Early Modern Spanish Studies: Essays, Newark, DL, Juan de la Cuesta, p. 89-106.

- (2013) «Cervantes, Zayas, and the Seven Deadly Sins», in E. O’Brien (ed.), Representing Women's Authority in the Early Modern World: Struggles, Strategies, and Morality, Rome, Aracne, p. 59-9I.

- (2014) The Life and Writings of Luisa de Carvajal y Mendoza. The Other Voice, Toronto, Iter-Centre for Renaissance and Reformation Studies Press.

- (2018) "Women's education in early modern Spain», in N. Baranda Leturio \& A. J. Cruz (eds.), The Routledge Research Companion to Early Modern Spanish Women Writers, New York, Routledge, p. 27-40.

Cruz, A. J. \& R. Hernández, eds. (20II) Women's Literacy in Early Modern Spain and the New World, Farnham, UK, Ashgate.

DADson, T. (1998) Libros, lectores y lecturas. Estudios sobre bibliotecas particulares españolas del Siglo de Oro, Madrid, Arco Libros. 
Donahue, D. (2018) «Foundation Narratives», in N. Baranda Leturio \& A. J. Cruz (eds.), The Routledge Research Companion to Early Modern Spanish Women Writers, New York, Routledge, p. 299-3I4.

Egido, A. (1998) «La Nobleza virtuosa de la Condesa de Aranda, dońa Luisa de Padilla, amiga de Gracián", Archivo de Filología Aragonesa, 54-55, p. 54-55.

Elk, M.van. (20I7) Early Modern Women's Writing: Domesticity, Privacy, and the Public Sphere in England and the Dutch Republic, New York, Palgrave McMillan.

Evangelisti, S. (2007) Nuns: A History of Convent Life, Oxford, Oxford University Press.

Fox, G. (2008) Subtle Subversions: Reading Golden Age Sonnets by Iberian Women, Washington, DC, Catholic University of America Press.

Gilmore, S., ed. (2008) Feminist Coalitions: Historical Perspectives on Second-wave Feminism in the United States, Urbana-Champaign: University of Illinois Press.

Howe, E. T. (20I6) Education and Women in the Early Modern Hispanic World, New York, Routledge.

Kaminsky, A., ed. (I996) "Ana Caro Mallén de Soto», Flores del agua, Minneapolis, University of Minnesota Press, p. 202-204.

Levy-Navarro, E. (2005) «The Religious Warrior: Luisa de Carvajal y Mendoza's Correspondence with Rodrigo de [sic] Calderón», in J. Couchman \& A. Crabb (eds.), Women's Letters Across Europe, I400-I700: Form and Persuasion, Aldershot, UK, Ashgate.

Luna, L. (I992) Ana Caro, una escritora profesional del Siglo de Oro: Vida y obra, Diss. Universidad de Sevilla.

Marcos SÁnchez, M. (20I8) «Chronicles, Biographies, Hagiographies», in N. Baranda Leturio \& A. J. Cruz (eds.), The Routledge Research Companion to Early Modern Spanish Women Writers, New York, Routledge, p. 75-85.

Marín Pina, M. C. (20I8) «Public Poetry», in N. Baranda Leturio \& A. J. Cruz (eds.), The Routledge Research Companion to Early Modern Spanish Women Writers, New York, Routledge, p. 205-218.

Martos, M. D. (20I8) «Poetic Voice», in N. Baranda Leturio \& A. J. Cruz (eds.), The Routledge Research Companion to Early Modern Spanish Women Writers, New York, Routledge, p. I35-I52.

Martos, M. D. \& J. NeIRA, eds. (20I8) Identidad autorial femenina y comunicación epistolar, Madrid, UNED.

Moll, J. (I982) «La primera edición de las Novelas amorosas y exemplares de María de Zayas y Sotomayor", Dicenda, I, p. I77-I79.

O’Brien, E. (20IO) Women in the Prose of Maria de Zayas, Woodbridge, UK, Tamesis. 
Olivares, J. (1995) «In Her Image: Christ and the Female Body in Women's Religious Poetry of the Golden Age», Caliope, I.I-2, p. III-I33.

-, ed. (2000) Maria de Zayas y Sotomayor. Novelas amorosas y ejemplares, Madrid, Cátedra.

- (2009a) "Género sexuado, género literario y la ansiedad de autoría en la poesía sacra de sor Violante del Cielo», in J. Olivares (ed.), Eros divino: estudios sobre la poesía religiosa iberoamericana del siglo XVII, Zaragoza, Prensas Universitarias de Zaragoza, p. 307-334.

— (2009b) «Vir melancholicus/Femina tristis: Towards a Poetics of Women's Loss», in J. Olivares (ed.), Studies on Women's Poetry of the Golden Age, Woodbridge, Tamesis, p. 19-50.

-, ed. (20I7) María de Zayas y Sotomayor. Honesto y entretenido Sarao (Primera y segunda parte), Zaragoza, Prensas Universitarias.

Olivares, J. \& E. Boyce, eds. (20I2) Tras el espejo la musa escribe: Lírica femenina de los Siglos de Oro Madrid, Akal / Siglo Xxi. [Revised 2a ed.]

Osuna, I. (20I8) «Literary Academies and Poetic Tournaments», in N. Baranda Leturio \& A. J. Cruz (eds.), The Routledge Research Companion to Early Modern Spanish Women Writers, New York, Routledge, p. I53-167.

Owens, S. E. (2017) Nuns Navigating the Spanish Empire, Albuquerque, University of New Mexico Press.

-, ed. (2009) Journey of Five Capuchin Nuns, Toronto, University of Toronto Press.

Pender, P. (2012) Early Modern Women's Writing and the Rhetoric of Modesty, New York, Palgrave Macmillan.

Poutrin, I. (20I8) «Autobiographies», in N. Baranda Leturio \& A. J. Cruz (eds.), The Routledge Research Companion to Early Modern Spanish Women Writers, New York, Routledge, p. 63-73.

Rhodes, E. (20II) Dressed to Kill: Death and Meaning in Zayas's Desengaños, Toronto, University of Toronto Press.

Romero-Díaz, N., ed. and trans. (2007) Maria de Guevara. Warnings to the Kings and Advice on Restoring Spain. The Other Voice, Chicago, University of Chicago Press.

Romero-Díaz, N. \& L. Vollendorf, eds. (2016) Women Playwrights of Early Modern Spain. Feliciana Enriquez de Guzmán, Ana Caro Mallén, and Sor Marcela de San Félix, Toronto, Iter.

Schlau, S. (20I8) «Body, Spirit, and Verse: Reading Early Modern Women's Religious Poetry», in N. Baranda Leturio \& A. J. Cruz (eds.), The Routledge Research Companion to Early Modern Spanish Women Writers, New York, Routledge, p. II5-I3I. 
Serrano y Sanz, M. (1903-1905) Apuntes para una biblioteca de escritoras españolas desde el año I40I al I833, vol. I, II, Madrid, Sucesores de Rivadeneyra.

Silverio de Santa Teresa (I9I5-I9I7) Obras de Santa Teresa de Jesús, Burgos, El Monte Carmelo.

Smith, S. M. \& G. Sabat-Rivers, eds. (2006) Los coloquios del alma; cuatro dramas alegóricos de Sor Marcela de San Félix, Newark, DL, Juan de la Cuesta.

Soufas, T. L., ed. (1997) Women's Acts: Plays by Women Dramatists of Spain's Golden Age, Lexington, University Press of Kentucky.

Weber, A. P. (1990) Teresa of Ávila and the Rhetoric of Femininity, Princeton, Princeton University Press.

Williamsen, A. (2018) «Women Playwrights», in N. Baranda Leturio \& A. J. Cruz (eds.), The Routledge Research Companion to Early Modern Spanish Women Writers, New York, Routledge, p. I87-202.

Zuese, A. (2OII) «Ana Caro and the Literary Academies of Seventeenth Century Spain», in A. J. Cruz \& R. Hernández (eds.), Women's Literacy in Early Modern Spain and the New World, Farnham, UK, Ashgate, p. I9I-208. 
